\title{
Sphingobacterium wenxiniae sp. nov., a cypermethrin-degrading species from activated sludge
}

Correspondence
Chengxiang Fang
cxfang@whu.edu.cn
Jian He
hejian@njau.edu.cn

\author{
Jun Zhang, ${ }^{1}$ Jin-Wei Zheng, ${ }^{1}$ Byung Cheol Cho, ${ }^{2}$ Chung Yeon Hwang, ${ }^{2}$ \\ Chengxiang Fang, ${ }^{3}$ Jian $\mathrm{He}^{1}$ and Shun-Peng $\mathrm{Li}^{1}$
}
${ }^{1}$ Key Laboratory for Microbiological Engineering of Agricultural Environment, Ministry of Agriculture, College of Life Sciences, Nanjing Agricultural University, Nanjing, Jiangsu 210095, PR China
${ }^{2}$ School of Earth and Environmental Sciences and Research Institute of Oceanography, Seoul National University, Shillim-dong, Kwanak-gu, Seoul 151-742, Republic of Korea

${ }^{3}$ College of Life Sciences, Wuhan University, Wuhan 430072, PR China

\begin{abstract}
A Gram-negative, non-motile, non-spore-forming, non-flagellated rod capable of degrading cypermethrin, designated LQY $-18^{\top}$, was isolated from activated sludge of a wastewater treatment plant in China. Strain LQY $-18^{\top}$ grew at $8-40{ }^{\circ} \mathrm{C}$ (optimum $30{ }^{\circ} \mathrm{C}$ ), at $\mathrm{pH} 5.0-10.0$ (optimum $\mathrm{pH} 7.0$ ) and with $0-5 \%(\mathrm{w} / \mathrm{v}) \mathrm{NaCl}$ (optimum 1\%). The predominant menaquinone was MK-7 (97\%) and the major fatty acids were summed feature 3 (comprising $\mathrm{C}_{16: 1} \omega 6 \mathrm{c}$ and/ or $\mathrm{C}_{16: 1} \omega 7 \mathrm{c}$ ), iso- $\mathrm{C}_{15: 0}$ and iso- $\mathrm{C}_{17: 0} 3-\mathrm{OH}$. The DNA G+C content was $40.3 \mathrm{~mol} \%$. Phylogenetic analysis revealed that the isolate belonged to the genus Sphingobacterium of the phylum Bacteroidetes and showed low 16S rRNA gene sequence similarity with recognized members of the genus Sphingobacterium. The closest neighbour was Sphingobacterium mizutaii ATCC $33299^{\top}$ (92.9\% 16S rRNA gene sequence similarity). On the basis of phenotypic, genetic and phylogenetic data, strain LQY $-18^{\top}\left(=\right.$ ACCC $05410^{\top}=$ CCTCC AB $2010005^{\top}=$ KCTC $23009^{\top}$ ) should be classified as a representative of a novel species of the genus Sphingobacterium, for which the name Sphingobacterium wenxiniae sp. nov. is proposed.
\end{abstract}

The genus Sphingobacterium was proposed by Yabuuchi et al. (1983) to include Gram-negative rods that are positive for catalase and oxidase but negative for heparinase, gelatinase and indole production and contain iso- $\mathrm{C}_{15: 0}$, iso- $\mathrm{C}_{15: 0} 2-\mathrm{OH}, \mathrm{C}_{16: 1} \omega 7 \mathrm{c}$ and $\mathrm{C}_{17: 0} 3-\mathrm{OH}$ as the main fatty acids (Takeuchi \& Yokota, 1992; Steyn et al., 1998). Sphingobacterium is the type genus of the family Sphingobacteriaceae (Steyn et al., 1998) in the phylum Bacteroidetes. At the time of writing, the genus comprised 17 recognized species, including the recently described species Sphingobacterium composti (Ten et al., 2006), Sphingobacterium daejeonense (Kim et al., 2006), Sphingobacterium anhuiense (Wei et al., 2008), Sphingobacterium canadense (Mehnaz et al., 2007), Sphingobacterium kitahiroshimense (Matsuyama et al., 2008), Sphingobacterium siyangense (Liu et al., 2008), Sphingobacterium bambusae (Duan et al. 2009) and Sphingobacterium shayense (He et al., 2010). The type species of the genus is Sphingobacterium spiritivorum.

The GenBank/EMBL/DDBJ accession number for the $16 \mathrm{~S}$ rRNA gene sequence of strain LQY $-18^{\top}$ is GQ988781.

A supplementary figure is available with the online version of this paper.
Cypermethrin is a synthetic pyrethroid widely used to control insect pests (Katsuda, 1999). It shows acute toxicity to a number of non-target organisms such as bees, fish and aquatic invertebrates (Smith \& Stratton, 1986; Saha \& Kaviraj, 2008). A cypermethrin-degrading bacterial strain, designated LQY $-18^{\mathrm{T}}$, was isolated from activated sludge of a wastewater treatment plant in a synthetic pyrethroidmanufacturing facility, using a procedure described elsewhere (Wang et al., 2009). The primary enrichment medium was mineral salts medium [MSM, containing $\left(\mathrm{l}^{-1}\right)$ : $4.8 \mathrm{~g} \mathrm{~K}_{2} \mathrm{HPO}_{4}, 1.2 \mathrm{~g} \mathrm{KH}_{2} \mathrm{PO}_{4}, 1.0 \mathrm{~g} \mathrm{NH}_{4} \mathrm{NO}_{3}, 0.2 \mathrm{~g}$ $\mathrm{MgSO}_{4} \cdot 7 \mathrm{H}_{2} \mathrm{O}, 0.4 \mathrm{~g} \mathrm{Ca}\left(\mathrm{NO}_{3}\right)_{2} \cdot 4 \mathrm{H}_{2} \mathrm{O}, 0.5 \mathrm{~g} \mathrm{NaCl}$ and $\left.0.001 \mathrm{~g} \mathrm{Fe}_{2}\left(\mathrm{SO}_{4}\right)_{3}\right]$ with $100 \mathrm{mg}$ cypermethrin as the sole carbon source. After five successive steps of subcultivation, the enrichment culture was spread on MSM agar and incubated at $30{ }^{\circ} \mathrm{C}$ for $4-5$ days. Strain LQY- $18^{\mathrm{T}}$ was obtained after several subcultivation steps on MSM agar.

Strain LQY $-18^{\mathrm{T}}$ was grown aerobically on trypticase soy agar (TSA; Difco) or in trypticase soy broth (TSB; Difco) at $30{ }^{\circ} \mathrm{C}$. Sphingobacterium mizutaii ATCC $33299^{\mathrm{T}}$, S. composti KCTC $12578^{\mathrm{T}}$, S. shayense CCTCC AB $209006^{\mathrm{T}}$, S. spiritivorum JCM $1277^{\mathrm{T}}$ and S. daejeonense KCTC $12579^{\mathrm{T}}$ 
were grown under the same conditions and used as reference strains in all physiological tests.

Cell morphology was determined by phase-contrast microscopy and transmission electron microscopy. Gliding motility was studied using the hanging-drop method (Bernardet et al., 2002). Gram-staining, catalase and oxidase activities, and hydrolysis of starch, DNA, Tweens 20 and 80 and carboxymethyl-cellulose were investigated as described by Smibert \& Krieg (1994). $\mathrm{H}_{2} \mathrm{~S}$ production was tested as described by Bruns et al. (2001). Growth at pH 4.0-10.0 (at intervals of $0.5 \mathrm{pH}$ units) was determined in TSB buffered with citrate/phosphate buffer or Tris/HCl buffer (Breznak \& Costilow, 1994). Growth with $0-7 \% \mathrm{NaCl}(w / v)$ (at intervals of $0.5 \%$ ) was tested in TSB. Growth at 4, 5, 10, 20, 25, 28, 30, 37, 40,41 and $45{ }^{\circ} \mathrm{C}$ was tested on TSA. Additional biochemical tests were performed using the API $20 \mathrm{NE}$, API $50 \mathrm{CH}$ and API ID32 GN kits and enzyme activities were assessed using the API ZYM kit (bioMérieux), according to the manufacturer's instructions. Sensitivity to antibiotics was determined using the disc-diffusion method with $8 \mathrm{~mm}$ diameter discs (Sanofi Pasteur) containing the following ( $\mu \mathrm{g}$ per disc): erythromycin (15), tetracycline (30), gentamicin (10), chloramphenicol (30), kanamycin (30), streptomycin (10), rifampicin (5), ampicillin (10), polymyxin B (30), penicillin G (10), cephradine (30), roxithromycin (15), lincomycin (2), carbenicillin (100), spectinomycin (100), amoxicillin (10), bacitracin (0.04) and vancomycin (30).

Cells of strain LQY- $18^{\mathrm{T}}$ were strictly aerobic, Gram-negative, non-motile, non-sporulating, non-flagellated, short rods with rounded ends. Other phenotypic characteristics of strain LQY $-18^{\mathrm{T}}$ are given in the species description and Table 1.

Extraction and purification of genomic DNA were carried out according to standard procedures (Sambrook \& Russell, 2001). Amplification of the 16S rRNA gene was performed using a universal bacterial primer set $(27 \mathrm{~F}$ and 1492R; Lane, 1991). The PCR product was purified and sequenced. The $16 \mathrm{~S}$ rRNA gene sequence of strain LQY $-18^{\mathrm{T}}$ was aligned with relevant sequences obtained from the EzTaxon server (http://www.eztaxon.org) (Chun et al., 2007) using MEGA4 and CLUSTAL w. Phylogenetic trees were constructed using the neighbour-joining (Saitou \& Nei, 1987), maximum-parsimony (Fitch, 1971) and minimumevolution (Rzhetsky \& Nei, 1992) methods, with bootstrap values based on 1000 replications (Felsenstein, 1985, 1993). Evolutionary distances were calculated using the Kimura two-parameter model (Kimura, 1980, 1983).

An almost-complete 16S rRNA gene sequence (1453 nt) of strain LQY $-18^{\mathrm{T}}$ was obtained. BLAST searches in the GenBank database and the EzTaxon server indicated that strain LQY- $18^{\mathrm{T}}$ belonged to the genus Sphingobacterium of the phylum Bacteroidetes and showed 89.1-92.9\% 16S rRNA gene sequence similarity with members of the genus. Phylogenetic analysis (Fig. 1) confirmed that strain LQY$18^{\mathrm{T}}$ belonged to the genus Sphingobacterium, forming a distinct lineage in a cluster containing S. shayense $\mathrm{HS}^{2} 9^{\mathrm{T}}$, and indicated that the isolate represents a novel member of the genus.

Table 1. Differential phenotypic characteristics of strain LQY $-18^{\top}$ and closely related members of the genus Sphingobacterium

Strains: 1, Sphingobacterium wenxiniae sp. nov. LQY-18 ${ }^{\mathrm{T}}$; 2, S. shayense CCTCC AB $209006^{\mathrm{T}}$; 3, S. composti KCTC $12578^{\mathrm{T}}$; 4, S. mizutaii ATCC $33299^{\mathrm{T}}$; 5, S. daejeonense KCTC $12579^{\mathrm{T}}$; 6, S. spiritivorum JCM $1277^{\mathrm{T}}$. All data were taken from this study. All strains are negative for Gram-staining, sporulation and indole production. + , Positive; w, weak; -, negative.

\begin{tabular}{|c|c|c|c|c|c|c|}
\hline Characteristic & 1 & 2 & 3 & 4 & 5 & 6 \\
\hline Temperature range $\left({ }^{\circ} \mathrm{C}\right)$ & $8-40$ & $10-40$ & $10-42$ & $10-40$ & $10-42$ & $5-42$ \\
\hline \multicolumn{7}{|l|}{ Hydrolysis of: } \\
\hline Starch & - & + & - & + & - & + \\
\hline Aesculin & + & + & - & + & - & + \\
\hline Urea & - & + & - & + & - & + \\
\hline \multicolumn{7}{|l|}{ Assimilation of: } \\
\hline Sorbitol & - & - & + & + & - & + \\
\hline L-Rhamnose & - & + & - & - & - & + \\
\hline D-Mannitol & - & - & + & - & - & + \\
\hline Glycogen & + & - & - & - & - & $\mathrm{W}$ \\
\hline L-Proline & + & - & - & + & - & - \\
\hline L-Fucose & + & - & - & - & - & - \\
\hline \multicolumn{7}{|l|}{ Acid production from: } \\
\hline L-Rhamnose & - & + & - & - & - & - \\
\hline D-Mannitol & - & - & - & - & - & + \\
\hline L-Arabinose & - & + & - & + & - & - \\
\hline Trehalose & + & + & W & - & - & - \\
\hline
\end{tabular}




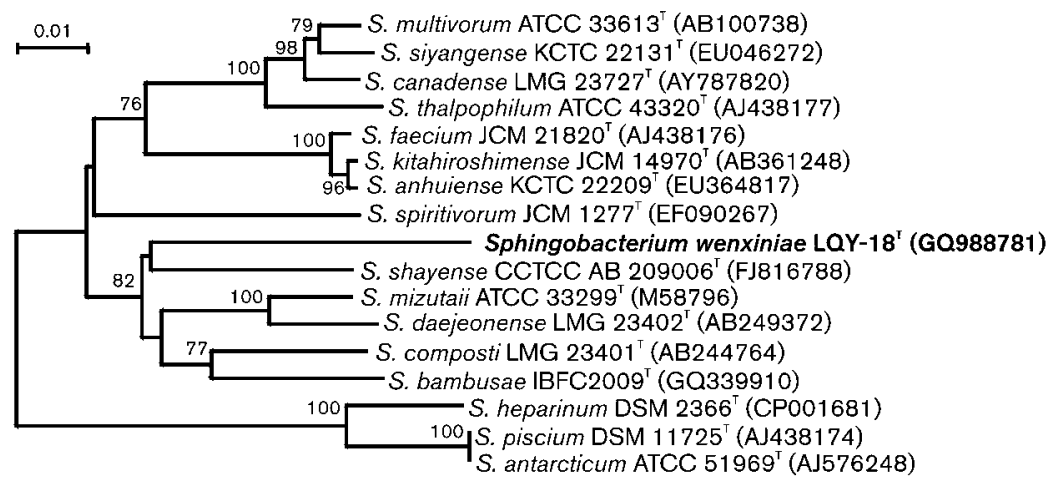

Fig. 1. Neighbour-joining phylogenetic tree based on 16S rRNA gene sequences showing the relationships of strain LQY $-18^{\top}$ and representative members of the genus Sphingobacterium. Bootstrap values ( $>70 \%$ ) based on 1000 replications are shown at branch nodes. Bar, 0.01 substitutions per nucleotide position.

Analysis of respiratory quinones was carried out by the identification service of the DSMZ and B. Tindall (Braunschweig, Germany). For fatty acid analysis, strain LQY $-18^{\mathrm{T}}$ and S. spiritivorum JCM $1277^{\mathrm{T}}$ were cultured on LB agar at $30{ }^{\circ} \mathrm{C}$ for $48 \mathrm{~h}$. The fatty acid methyl esters were obtained from cells by saponification, methylation and extraction as described elsewhere (Kämpfer \& Kroppenstedt, 1996) and were separated by GC (Agilent $6890 \mathrm{~N})$. Peaks were automatically integrated and fatty acid names and percentages were determined using the MIDI Sherlock MIS system (TSBA6 library version 6.0B) (Sasser, 1990). Quinones were extracted using an integrated protocol as described elsewhere (Tindall 1990a, b; Altenburger et al., 1996). Polar lipids were extracted by the method of Minnikin et al. (1984) and identified by twodimensional TLC and spraying with specific reagents as described by Collins \& Jones (1980). The DNA G+ $\mathrm{C}$ content was determined by thermal denaturation (Marmur \& Doty, 1962) using Escherichia coli K-12 as the standard.

Strain LQY-18 ${ }^{\mathrm{T}}$ contained iso- $\mathrm{C}_{15: 0}(32.4 \%)$, iso- $\mathrm{C}_{17: 0} 3-$ $\mathrm{OH}(15.2 \%)$ and summed feature 3 (comprising $\mathrm{C}_{16: 1} 1 \omega 6 c$ and/or $\mathrm{C}_{16: 1} \omega 7 c, 33.8 \%$ ) as the major fatty acids. The fatty acid profiles of strain LQY $-18^{\mathrm{T}}$ and the reference strains were similar, although there were some differences in the proportions of some components. The detailed fatty acid compositions of strain LQY $-18^{\mathrm{T}}$ and the reference strains are given in Table 2. The predominant isoprenoid quinone of strain LQY-18 ${ }^{\mathrm{T}}$ was MK-7 (97\%). The major polar lipid was phosphatidylethanolamine; several unknown polar lipids were also detected (Supplementary Fig. S1, available in IJSEM Online). Strain LQY $-18^{\mathrm{T}}$ and S. spiritivorum JCM $1277^{\mathrm{T}}$ contained sphingolipid, which is a distinct feature of members of the genus Sphingobacterium. The DNA G + C content of strain LQY- $18^{\mathrm{T}}$ was $40.3 \mathrm{~mol} \%$, which fell within the range observed for the genus Sphingobacterium (36.0$44.2 \mathrm{~mol} \%$ ).

On the basis of phenotypic, genotypic and phylogenetic properties, strain LQY-18 $8^{\mathrm{T}}$ should be classified as a representative of a novel species of the genus Sphingobacterium, for which the name Sphingobacterium wenxiniae sp. nov. is proposed.

\section{Description of Sphingobacterium wenxiniae sp. nov.}

Sphingobacterium wenxiniae (wen.xi.ni'a.e. N.L. fem. gen. n. wenxiniae of Wen-xin, to honour Wen-xin Chen, a respected soil microbiologist, for her great contributions to the investigation and development of Rhizobia resources in China).

Cells are Gram-negative, non-motile, non-spore-forming, non-flagellated, strictly aerobic rods, approximately $0.6-$ $1.4 \mu \mathrm{m}$ in length and $0.3-0.6 \mu \mathrm{m}$ in diameter. After 3 days of incubation on TSA, colonies are $1.0-2.0 \mathrm{~mm}$ in diameter, yellowish, convex, circular and smooth with entire margins. Grows with $0-5 \%(w / v) ~ N a C l$ (optimum $1 \%$ ), at pH 5.0-10.0 (optimum $\mathrm{pH} 7.0-8.0$ ) and at 8$40{ }^{\circ} \mathrm{C}$ (optimum $30{ }^{\circ} \mathrm{C}$ ). $\mathrm{H}_{2} \mathrm{~S}$ and indole are not produced. Nitrate is not reduced. Aesculin, Tweens 20 and 80, and carboxymethyl-cellulose are hydrolysed, but starch, urea, DNA and gelatin are not. Catalase, oxidase, alkaline phosphatase, esterase (C4), esterase lipase (C8), cystine arylamidase, leucine arylamidase, valine arylamidase, trypsin, $\alpha$-chymotrypsin, acid phosphatase, naphthol-ASBI-phosphohydrolase, $\alpha$ - and $\beta$-galactosidases, $\alpha$ - and $\beta$ glucosidases, $N$-acetyl- $\beta$-glucosaminidase and $\alpha$-fucosidase are present, but arginine dihydrolase, urease, arginine decarboxylase, ornithine decarboxylase, lysine decarboxylase, lipase (C14), $\beta$-glucuronidase and $\alpha$-mannosidase are absent. Assimilates D-glucose, D-mannose, $N$-acetylglucosamine, maltose, salicin, melibiose, L-fucose, glycogen, sucrose and L-proline, but not L-arabinose, gluconate, Lrhamnose, L-arabitol, L-histidine, D-ribose, inositol, itaconic acid, suberic acid, sodium malonate, sodium acetate, lactic acid, L-alanine, potassium 5-ketogluconate, 3-hydroxybenzoic acid, L-serine, D-mannitol, D-sorbitol, propionic acid, capric acid, valeric acid, trisodium, citrate, potassium 2-ketogluconate, 3-hydroxybutyric acid or 4-hydroxybenzoic acid. Acid is produced from D-arabinose, D-galactose, D-glucose, D-fructose, D-mannose, methyl $\alpha$-D-mannoside, methyl $\alpha$-D-glucoside, $N$-acetylglucosamine, amygdalin, arbutin, aesculin, salicin, cellobiose, maltose, lactose, melibiose, trehalose, sucrose, inulin, melezitose, raffinose, starch, glycogen, D-gentiobiose, turanose and L-fucose, but not from glycerol, mannitol, erythritol, L-arabinose, D-ribose, D- and 
Table 2. Cellular fatty acid contents of strain LQY $-18^{\top}$ and closely related members of the genus Sphingobacterium

Strains: 1, Sphingobacterium wenxiniae sp. nov. LQY- $18^{\mathrm{T}}$; 2, S. spiritivorum JCM $1277^{\mathrm{T}}$; 3, S. shayense CCTCC AB $209006^{\mathrm{T}}$; 4, S. composti KCTC $12578^{\mathrm{T}}$; 5, S. mizutaii ATCC $33299^{\mathrm{T}}$; 6, S. daejeonense KCTC $12579^{\mathrm{T}}$. Data for columns 1 and 2 were taken from this study and for columns 3-6 from He et al. (2010). tr, Trace (<1\%); - , not detected.

\begin{tabular}{|c|c|c|c|c|c|c|}
\hline Fatty acid & 1 & 2 & 3 & 4 & 5 & 6 \\
\hline $\mathrm{C}_{14: 0}$ & $\operatorname{tr}$ & 2.1 & 1.3 & - & - & - \\
\hline $\mathrm{C}_{16: 0}$ & 4.8 & 4.3 & 3.5 & 1.1 & 1.7 & 2.0 \\
\hline $\mathrm{C}_{18: 0}$ & $\operatorname{tr}$ & $\operatorname{tr}$ & $\operatorname{tr}$ & 1.0 & 1.0 & 1.0 \\
\hline $\mathrm{C}_{16: 0} 3-\mathrm{OH}$ & 1.9 & 4.3 & 2.4 & $\operatorname{tr}$ & $\operatorname{tr}$ & $\operatorname{tr}$ \\
\hline $\mathrm{C}_{17: 0} 2-\mathrm{OH}$ & $\operatorname{tr}$ & $\operatorname{tr}$ & 1.1 & $\operatorname{tr}$ & $\operatorname{tr}$ & 3.4 \\
\hline iso- $\mathrm{C}_{15: 0}$ & 32.4 & 25.5 & 28.6 & 38.0 & 38.3 & 32.3 \\
\hline iso- $\mathrm{C}_{15: 0} 3-\mathrm{OH}$ & 2.0 & 2.5 & 2.5 & 2.0 & 1.6 & 1.0 \\
\hline iso- $\mathrm{C}_{17: 0} 3-\mathrm{OH}$ & 15.2 & 9.5 & 13.5 & 17.4 & 18.0 & 15.7 \\
\hline $\mathrm{C}_{16: 1} \omega 5 c$ & $\operatorname{tr}$ & 1.4 & 1.0 & $\operatorname{tr}$ & $\operatorname{tr}$ & - \\
\hline anteiso- $\mathrm{C}_{15: 0}$ & 1.5 & $\operatorname{tr}$ & 3.2 & $\operatorname{tr}$ & 2.9 & 7.8 \\
\hline \multicolumn{7}{|c|}{ Summed features ${ }^{*}$} \\
\hline 1 & $\operatorname{tr}$ & $\operatorname{tr}$ & $\operatorname{tr}$ & 1.9 & 1.3 & $\operatorname{tr}$ \\
\hline 3 & 33.8 & 41.6 & 37.0 & 19.2 & 20.5 & 24.4 \\
\hline 4 & $\operatorname{tr}$ & 1.6 & $\operatorname{tr}$ & $\operatorname{tr}$ & 1.1 & $\operatorname{tr}$ \\
\hline 9 & 1.8 & 2.3 & $\operatorname{tr}$ & 9.5 & 5.1 & 2.8 \\
\hline
\end{tabular}

*Summed features represent two or three fatty acids that cannot be separated by the Microbial Identification System. Summed feature 1 consisted of $\mathrm{C}_{13: 0} 3-\mathrm{OH}$ and/or iso- $\mathrm{C}_{15: 1} \mathrm{H}$. Summed feature 3 consisted of $\mathrm{C}_{16: 1} \omega 6 c$ and/or $\mathrm{C}_{16: 1} \omega 7 c$. Summed feature 4 consisted of anteiso- $\mathrm{C}_{17: 1} \mathrm{~B}$ and/or iso- $\mathrm{C}_{17: 1}$ I. Summed feature 9 consisted of iso- $\mathrm{C}_{17: 1} \omega 9 c$ and/or 10-methyl $\mathrm{C}_{16: 0}$.

L-xylose, D-adonitol, methyl $\alpha$-D-xyloside, L-sorbose, Lrhamnose, dulcitol, inositol, sorbitol, xylitol, D-lyxose, D-tagatose, D-fucose, D- or L-arabitol, gluconate, 2-ketogluconate or 5-ketogluconate. Sensitive to roxithromycin, erythromycin, chloramphenicol, rifampicin, spectinomycin and cephradine; resistant to tetracycline, gentamicin, kanamycin, streptomycin, ampicillin, polymyxin $B$, penicillin $G$, lincomycin, carbenicillin, amoxicillin, bacitracin and vancomycin. The major respiratory quinone is MK-7. The major polar lipid is phosphatidylethanolamine; an unknown aminolipid and several unknown polar lipids are also detected. Sphingolipid is present. The major cellular fatty acids are summed feature $3\left(\mathrm{C}_{16: 1} \omega 6 c\right.$ and/or $\left.\mathrm{C}_{16: 1} \omega 7 c\right)$, iso$\mathrm{C}_{15: 0}$ and iso- $\mathrm{C}_{17: 0} 3-\mathrm{OH}$.

The type strain, LQY $-18^{\mathrm{T}}\left(=\right.$ ACCC $05410^{\mathrm{T}}=$ CCTCC AB $2010005^{\mathrm{T}}=$ KCTC $23009^{\mathrm{T}}$ ), was isolated from activated sludge of a wastewater treatment plant in a synthetic pyrethroidmanufacturing facility of the Yangnong Chemical Group, Jiangsu Province, China. The DNA G $+\mathrm{C}$ content of the type strain is $40.3 \mathrm{~mol} \%$.

\section{Acknowledgements}

This work was supported by the National Natural Science Foundation of China (30970099), the Natural Science Foundation of Jiangsu Province, China (BK2008331), the National High Technology Research and Development Program of China (2006AA10Z402) and the BK21 project of the Korean Government (BCC).

\section{References}

Altenburger, P., Kämpfer, P., Makristathis, A., Lubitz, W. \& Busse, H.-J. (1996). Classification of bacteria isolated from a medieval wall painting. J Biotechnol 47, 39-52.

Bernardet, J.-F., Nakagawa, Y., Holmes, B. \& Subcommittee on the taxonomy of Flavobacterium and Cytophaga-like bacteria of the International Committee on Systematics of Prokaryotes (2002). Proposed minimal standards for describing new taxa of the family Flavobacteriaceae and emended description of the family. Int J Syst Evol Microbiol 52, 1049-1070.

Breznak, J. A. \& Costilow, R. N. (1994). Physicochemical factors in growth. In Methods for General and Molecular Bacteriology, pp. 137-154. Edited by P. Gerhardt, R. G. E. Murray, W. A. Wood \& N. R. Krieg. Washington, DC: American Society for Microbiology.

Bruns, A., Rohde, M. \& Berthe-Corti, L. (2001). Muricauda ruestringensis gen. nov., sp. nov., a facultatively anaerobic, appendaged bacterium from German North Sea intertidal sediment. Int $J$ Syst Evol Microbiol 51, 1997-2006.

Chun, J., Lee, J.-H., Jung, Y., Kim, M., Kim, S., Kim, B. K. \& Lim, Y.-W. (2007). EzTaxon: a web-based tool for the identification of prokaryotes based on $16 \mathrm{~S}$ ribosomal RNA gene sequences. Int J Syst Evol Microbiol 57, 2259-2261.

Collins, M. D. \& Jones, D. (1980). Lipids in the classification and identification of coryneform bacteria containing peptidoglycans based on 2,4-diaminobutyric acid. J Appl Bacteriol 48, 459-470.

Duan, S., Liu, Z., Feng, X., Zheng, K. \& Cheng, L. (2009). Sphingobacterium bambusae sp. nov., isolated from soil of bamboo plantation. J Microbiol 47, 693-698. 
Felsenstein, J. (1985). Confidence limits on phylogenies: an approach using the bootstrap. Evolution 39, 783-791.

Felsenstein, J. (1993). PHYLIP (phylogeny inference package) version 3.5c. Distributed by the author. Department of Genome Sciences, University of Washington, Seattle, USA.

Fitch, W. M. (1971). Toward defining the course of evolution: minimum change for a specific tree topology. Syst Zool 20, 406-416.

He, X., Xiao, T., Kuang, H., Lan, X., Tudahong, M., Osman, G., Fang, C. \& Rahman, E. (2010). Sphingobacterium shayense sp. nov., isolated from forest soil. Int J Syst Evol Microbiol 60, 2377-2381.

Kämpfer, P. \& Kroppenstedt, R. M. (1996). Numerical analysis of fatty acid patterns of coryneform bacteria and related taxa. Can $J$ Microbiol 42, 989-1005.

Katsuda, Y. (1999). Development of and future prospects for pyrethroid chemistry. Pestic Sci 55, 775-782.

Kim, K.-H., Ten, L. N., Liu, Q.-M., Im, W.-T. \& Lee, S.-T. (2006). Sphingobacterium daejeonense sp. nov., isolated from a compost sample. Int J Syst Evol Microbiol 56, 2031-2036.

Kimura, M. (1980). A simple method for estimating evolutionary rates of base substitutions through comparative studies of nucleotide sequences. J Mol Evol 16, 111-120.

Kimura, M. (1983). The Neutral Theory of Molecular Evolution. Cambridge: Cambridge University Press.

Lane, D. J. (1991). 16S/23S rRNA sequencing. In Nucleic Acid Techniques in Bacterial Systematics, pp. 115-175. Edited by E. Stackebrandt \& M. Goodfellow. Chichester: Wiley.

Liu, R., Liu, H., Zhang, C.-X., Yang, S.-Y., Liu, X.-H., Zhang, K.-Y. \& Lai, R. (2008). Sphingobacterium siyangense sp. nov., isolated from farm soil. Int J Syst Evol Microbiol 58, 1458-1462.

Marmur, J. \& Doty, P. (1962). Determination of the base composition of deoxyribonucleic acid from its thermal denaturation temperature. J Mol Biol 5, 109-118.

Matsuyama, H., Katoh, H., Ohkushi, T., Satoh, A., Kawahara, K. \& Yumoto, I. (2008). Sphingobacterium kitahiroshimense sp. nov., isolated from soil. Int J Syst Evol Microbiol 58, 1576-1579.

Mehnaz, S., Weselowski, B. \& Lazarovits, G. (2007). Sphingobacterium canadense sp. nov., an isolate from corn roots. Syst Appl Microbiol 30, 519-524.

Minnikin, D. E., O’Donnell, A. G., Goodfellow, M., Alderson, G., Athalye, M., Schaal, A. \& Parlett, J. H. (1984). An integrated procedure for the extraction of bacterial isoprenoid quinones and polar lipids. J Microbiol Methods 2, 233-241.

Rzhetsky, A. \& Nei, M. (1992). A simple method for estimating and testing minimum-evolution trees. Mol Biol Evol 9, 945-967.

Saha, S. \& Kaviraj, A. (2008). Acute toxicity of synthetic pyrethroid cypermethrin to some freshwater organisms. Bull Environ Contam Toxicol 80, 49-52.
Saitou, N. \& Nei, M. (1987). The neighbor-joining method: a new method for reconstructing phylogenetic trees. Mol Biol Evol 4, 406-425.

Sambrook, J. \& Russell, D. W. (2001). Molecular Cloning: a Laboratory Manual. Cold Spring Harbor, NY: Cold Spring Harbor Laboratory.

Sasser, M. (1990). Identification of bacteria by gas chromatography of cellular fatty acids, MIDI Technical Note 101. Newark, DE: MIDI Inc.

Smibert, R. M. \& Krieg, N. R. (1994). Phenotypic characterization. In Methods for General and Molecular Bacteriology, pp. 607-654. Edited by P. Gerhardt, R. G. E. Murray, W. A. Wood \& N. R. Krieg. Washington, DC: American Society for Microbiology.

Smith, T. M. \& Stratton, G. W. (1986). Effects of synthetic pyrethroid insecticides on nontarget organisms. Residue Rev 97, 93-120.

Steyn, P. L., Segers, P., Vancanneyt, M., Sandra, P., Kersters, K. \& Joubert, J. J. (1998). Classification of heparinolytic bacteria into a new genus, Pedobacter, comprising four species: Pedobacter heparinus comb. nov., Pedobacter piscium comb. nov., Pedobacter africanus sp. nov. and Pedobacter saltans sp. nov. Proposal of the family Sphingobacteriaceae fam. nov. Int J Syst Bacteriol 48, 165-177.

Takeuchi, M. \& Yokota, A. (1992). Proposals of Sphingobacterium faecium sp. nov., Sphingobacterium piscium sp. nov., Sphingobacterium heparinum comb. nov., Sphingobacterium thalpophilum comb. nov., and two genospecies of the genus Sphingobacterium and synonymy of Flavobacterium yabuuchiae and Sphingobacterium spiritivorum. J Gen Appl Microbiol 38, 465-482.

Ten, L. N., Liu, Q.-M., Im, W.-T., Aslam, Z. \& Lee, S.-T. (2006). Sphingobacterium composti sp. nov., a novel DNase-producing bacterium isolated from compost. J Microbiol Biotechnol 16, 17281733.

Tindall, B. J. (1990a). Lipid composition of Halobacterium lacusprofundi. FEMS Microbiol Lett 66, 199-202.

Tindall, B. J. (1990b). A comparative study of the lipid composition of Halobacterium saccharovorum from various sources. Syst Appl Microbiol 13, 128-130.

Wang, B.-Z., Guo, P., Hang, B.-J., Li, L., He, J. \& Li, S.-P. (2009). Cloning of a novel pyrethroid-hydrolyzing carboxylesterase gene from Sphingobium sp. strain JZ-1 and characterization of the gene product. Appl Environ Microbiol 75, 5496-5500.

Wei, W., Zhou, Y., Wang, X., Huang, X. \& Lai, R. (2008). Sphingobacterium anhuiense sp. nov., isolated from forest soil. Int $J$ Syst Evol Microbiol 58, 2098-2101.

Yabuuchi, E., Kaneko, T., Yano, I., Moss, C. W. \& Miyoshi, N. (1983). Sphingobacterium gen. nov., Sphingobacterium spiritivorum comb. nov., Sphingobacterium multivorum comb. nov., Sphingobacterium mizutae sp. nov., and Flavobacterium indologenes sp. nov.: glucosenonfermenting Gram-negative rods in CDC groups IIK-2 and IIb. Int J Syst Bacteriol 33, 580-598. 